\title{
Czech Republic ANd Processes of INDUSTRY 4.0 IMPLEMENTATION
}

\author{
Peter Poor, Josef Basl
}
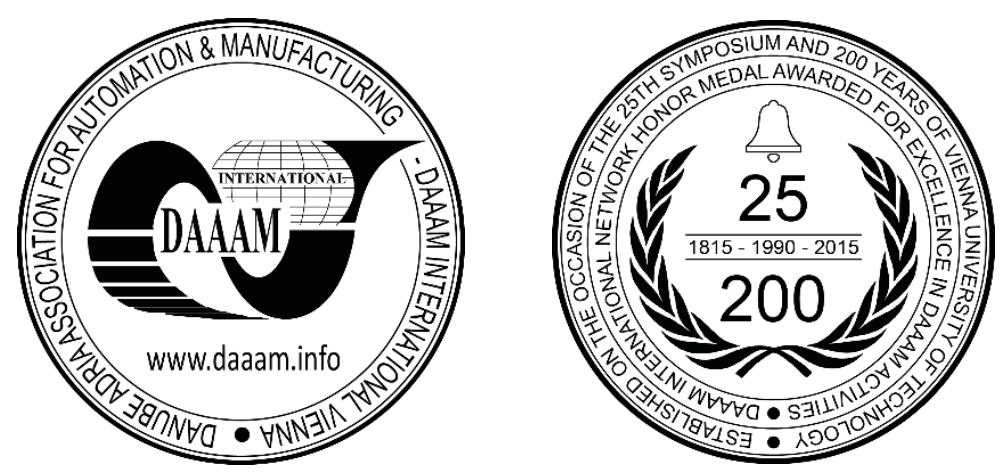

This Publication has to be referred as: Poor, P[eter] \& Basl, J[osef] (2018). Czech Republic and Processes of Industry 4.0 Implementation, Proceedings of the 29th DAAAM International Symposium, pp.0454-0459, B. Katalinic (Ed.), Published by DAAAM International, ISBN 978-3-902734-20-4, ISSN 1726-9679, Vienna, Austria DOI: $10.2507 / 29$ th.daaam.proceedings.067

\begin{abstract}
This publication shortly describes the processes of Industry 4.0 implementation in Czech Republic. Firstly, concept of Industry 4.0 (and what lead to it - Industry revolutions 1-3) is presented. This is specifically targeted to Czech Republic. Next part describes various areas of Industry 4.0 implementation in Czech Republic. Main parts of industry and education are covered here. The main part of the article dealt with data analysis (about Czech Republic and its readiness to Industry 4.0) - based mainly on The Digital Economy \& Society Index. The final part deals with conclusions and further development.
\end{abstract}

Keywords: Industry 4.0; Czech Republic, implementation; processes

\section{History of Industry with accent of Industrial Revolutions in Czech Republic}

When mentioning the term Industry 4.0, some know exactly what this is all about, some may know, but many do not know what they are supposed to imagine. According to many expressions of a wide range of experts refer to Industry 4.0 revolution that is currently ongoing. The very word "Revolution," the definition of which should express something that suddenly changes society in a revolutionary manner with all its particulars, should mean that it is a phenomenon that will sooner or later each of us. That is why first it is needed to recall the first three industrial revolutions and to mention what they meant for the development of country and company. The next part of the article will not deal with industrial revolutions in general, but specifically in the region of Czech Republic.

\subsection{First Industrial revolution (Czech Republic)}

At the time of the First Industrial Revolution, the Austrian Monarchy existed. There was a Czech territory with population from 5 million to 6 million, from 1818 to 1830. The technical education and development of railway and inland waterway transport improved. Czech inventions included shipping screw and bell. The first modern engineering workshops were built in Prague, Brno and Liberec. In the northern Bohemia, textile production expanded in Prague and Brno. In the Ostrava region stone mining began and produce iron. In 1821 for the first time in the whole monarchy coal was cast by stone coal coke in the ironworks of Count Kašpar Šternberg in Darová near Rokycany. 
The same year, first rolling mills in Ondřejovice at the Golden Mountains, Blansko, Vítkovice... In 1828 ironworks were founded in Ostrava - Vítkovice, which are today a cultural monument. In 1836, the first coke blast furnace was built in the monarchy. The domestic financial sector was developing. The first Spořitelna česká (financial institution in the Czech Republic) was established in 1825 and a few years later the first Czech insurance company Česká vzájemná pojišt'ovna. The paper industry has also begun to develop. In 1833 the first paper mill in Císařský Mlýn was established in Bubeneč, Prague. In 1842 a town brewery (future Prazdroj) was established in Pilsen, one of the most successful businesses. In the same year Josef Groll brewed the first Pilsen beer in the world. During this period, the lowest employment in agriculture in the Czech lands was within the framework of the monarchy. The economy of the monarchy influenced the following factors:

- Absence of colonies - meant a smaller market.

- Later onset of industrialization - applied unevenly from West to East. Some areas have been delayed for up to 100 years in industrial development.

- Slow pace of economic development - means lagging:

○ small sources of raw materials,

$\circ$ the surplus of cheap labour, so there was no need to buy expensive machines,

- slow market development,

- lack of capital,

○ unfavourable impact of the political system. [1]

\subsection{Second Industrial revolution (Czech Republic)}

The territory of Bohemia was also affected by new technologies of this time. The first telegraph in the country was established in the year 1846 from Vienna to Brno and was originally intended for official purposes. For private purposes, it was used the first time in 1850. By the beginning of the First World War, there were 1,700 telegraphs on territory stations. In the economy, the role of communication and, consequently, mail has grown. The same year 1850 was first released postage stamps in Austria, postal vouchers, and a year later also a post office. The first phone connection was introduced in 1881 in Prague, 2 years later the telephone network expanded to other cities - Brno, Liberec, and Pilsen. At the beginning of the war, there were 35,000 telephone numbers on the Czech territory.

For the Czech industry, the chemical industry was important. The development of transport has been produced in the Czech Republic railway wagons (freight and passenger), trams, locomotives. In 1869 a bank was established in Prague Živnostenská banka, which became the main centre of Czech capital. Two years later, the Prague Stock Exchange was established. The mechanical factories in Valdštejn were founded in 1859 in Plzeň, Ten years later the bourgeois entrepreneur Emil Škoda took over, which of them until the end of the century created an engineering giant. At the end of the century, the automotive industry started in the Czech Republic. The roots go to the President brand, which was a car with a combustion engine. In 1899 Mladá Boleslav Laurin and Klement began production of Slavia motorcycles. Till beginning of the war 2500 cars and 4000 motorcycles were racing in the Czech lands. As far as the invention of electricity is concerned, in 1880 electric lighting was introduced at the first factory, the Židlochovice sugar factory. The first publicly lit town was in 1888 - Jindřichův Hradec.

Since the second half of the 19th century, the share of Czech lands in the industrial production of the Austrian monarchy even exceeded 70 percent. The industry was here at a high level and helped to make significant discoveries for this revolution that took place in our country. For example, the company Tatra, based in Koprivnica, which is one of the oldest car manufacturers in the world, behind automobile manufacturing NW Präsident, which became in 1898 the first production car in the functional throughout Central Europe. The inventor Frantisek Krrizík - the tramcar maker in Prague and the first electric railway in Austria-Hungary - participated in the development of industrialization in the Czech Republic in an indispensable way. Mention must also be an electrical engineer Emil Kolben, the designer series of electrically operated machines and also co-founder of a major engineering company ČKD.3 The examples of technological development, leaning against the scientific findings indicate a boom in the engineering industry and the subsequent development of transport. Thanks to a much better transport infrastructure, large industrial centres (Prague, Pilsen) were established in the Czech Republic, where production was centralized. As a result, the population grew in the big cities, the city was also upgraded - the street lighting was being built, the medieval city walls were being cut down, urban public transport started to work. Liberal policy in the area of economics also contributed to the boom of industry, which meant supporting business and production.

\subsection{Third Industrial revolution (Czech Republic)}

In Czechoslovakia, the industry was heavily influenced by the political situation and the production orientation was mainly heavy mechanical and metallurgical. There has been no such close interconnection of the scientific and industrial sectors, which, coupled with limited contact with the Western countries that have led the revolution, has caused a slowdown in technological innovation. The machines in the Czechoslovak factories were thus much more difficult and obsolete than those in the factories in the West, even though most of the investments went to industry, but often ineffective. There has not been such a great development of cybernetics. While the industrial sector was still the leading element of the economy, labour productivity slowly declined. 
From the above mentioned you can see that industrial production has deep historical roots in the Czech Republic). In the times of Austria-Hungary, the Czech lands formed an industrial base. After the breakup in Czechoslovakia remained about $70 \%$ of the industrial enterprises of the entire monarchy. After the establishment of the independent Czechoslovak Republic, the industry developed so much that it did rank among the industrially most developed countries in the world. In 1920, the minimum delay was the industrial world at the onset of the 2nd Industrial Revolution, which concerned the establishment of mass production [9]. After 1950, there were only a few competitive industries. Since 1990 The Czech Republic catches the world of the 3rd Industrial Revolution. Industry accounts for 35\% of the Czech economy and employs over $40 \%$ of the economically active population. The main pillars of industry include engineering, metallurgical, chemical and food industries. Czech Republic is one of the countries with the longest industrial tradition and the great ambition is for its future to be furthermore connected with the industry. That is why the fourth industrial revolution for the Czech Republic is a big challenge, and especially the ability to maintain and strengthen long-term competitiveness in global competition environment. Elements of Industry 4.0 have been handled by Czech experts since the 1990s. Since 2013, there has been steadily growing industrial manufacture of motor vehicles, trailers and semi-trailers, rubber and plastic products, electrical equipment, electronic and optical instruments and devices [12].

\section{Current situation of Industry 4.0 implementation in Czech Republic}

Czech industry as such has a very good starting point compared to the rest of Europe position, according to the assessment as the share of industry in value in the economy. This advantage, however is also a risk that more the Czech economy could lose if it lost its competitiveness in this area. [2]

Great importance for achieving readiness to implement the principles of the Fourth Industrial Revolution is the support that the public sector spends on research and innovation, methods and approaches educational institutions, support for information and communication technologies, etc. [5] At present, too much emphasis is not on innovation and development compared with Western European countries, and therefore the Czech Republic should take an example in this respect research and development funding in these countries. In terms of technology, the Czech Republic is in the forefront, but the fourth industrial revolution is cybernetic and is therefore more revolution in thinking people rather than in specific technologies [11]. Currently, there is training for specialists conducted in a different way than is required for their application in Industry Principle 4.0, is little emphasis is placed on mathematics and physics that are important for managing complexity distribution systems [6]. There is a need to improve the readiness of the Czech Republic for digitization.

Great responsibility lies also on the looms of industrial enterprises and their access to implementation and investing in technological innovation and new concepts. By group led prof. Maurik is the key ownership structure of businesses. It is possible to divide businesses into three groups according to this criterion. These are the Czech branches of multinational corporations which are basically unable to determine themselves when and how to implement new processes. Other group are Czech companies owned by a large financial group and are therefore more prone to the short-term vision of the company's management and thus are less likely to be able to become a leader in the Czech market in the transition to Industry 4.0. The third group that appears the most important and essential are the small and medium-sized enterprises that have the possibility of their future to make full decisions. However, there may be a shortage of funds for these businesses and information. [2]

Within the framework of the conference "How to be part of Industry 4.0" held in Prague in July 2016 an inquiry has been made whether Czech companies have already embarked on a new industrial revolution and whether they have already some measures [7. This poll showed that only Czech and Slovak companies are 10 percent of those who have already stepped some way towards Industry 4.0 and half of these companies said they were interested in starting, but they did not have enough information. According to the CZECH NATIONAL BANK, we would find it hard to find a more appropriate moment for implementing the basic pillars Industry 4.0 to the functioning of Czech companies. The Czech Republic is therefore based on this information ready to move to the principles of Industry 4.0, but more knowledge is needed and new trends into the whole society. [10]

The European Commission uses the progress made in developing the digital economy and the digital society to assess progress index DESI (The Digital Economy \& Society Index). The DESI index summarizes the relevant indicators on Europe's digital performance and monitors the evolution of EU countries in digital competitiveness. It is a set of relevant indicators grouped into five areas: connectivity, human capital, the use of the Internet, the integration of digital technologies and digital public services. Result of index is in the interval $(0,1)$ and the higher the number, the better the country [15].

Czech Republic achieved a score of 0.5 with the DESI 2017 index (based on results from 2016) which makes it ranked 17th among EU Member States. The Czech Republic falls into the group of lagging behind because it's DESI score is below the EU average. Worst countries further include: Bulgaria, France, Hungary, Poland, Greece and Slovakia. The number of users who have access to broadband and mobile broadband connection is increasing. Czechs have a good level of digital skills and they are using the internet to a variety of activities. Internet users most often use internet banking and shopping [16].

Companies in the Czech Republic use digital technologies to increase their efficiency and productivity access to wider markets. They rank at the top in terms of turnover from online sales. Compared to 2015 the Czech Republic has made no significant progress. In addition, it achieves below-average performance in securing digital public services. 


\subsection{Connectivity}

In the area of connection, the results and progress of the Czech Republic are at the level corresponding to the average EU. The country maintains its level of coverage by fixed broadband in the case of households to $98 \%$, and progressing to $73 \%$ coverage by NGA networks, its results are slightly better than the EU average. However, in rural areas next generation access (NGA) coverage for households is only 6\%; It is well below the EU average of $28 \%$. Share of subscribers with a fixed purchase agreement broadband is $31 \%$, which is slightly above the EU average, which is $30 \%$. With regard to mobile networks, LTE networks are covered by over $90 \%$ of the population. However, with regard to the allocation of the harmonized band, the Czech Republic with $55 \%$ was included in the EU at $23^{\text {rd }}$ place. Selection procedure (see paragraph below) for the $1800 \mathrm{MHz}$ and $2600 \mathrm{MHz}$ frequency bands announced on 3 February 2016, would be expected to increase the band allocations to $64 \%$ but I this is below the EU average of $64 \%$. As far as the proportion of participants is concerned with a contract for mobile broadband subscription, the Czech Republic is below the EU average.

In the 2014-2020 programming period, the Czech Republic has earmarked a significant part of European structural funds and investment funds for the deployment of broadband infrastructure. In the Operational Program Enterprise and Innovation for Competitiveness (hereinafter referred to as "OPIE") is available at EUR 520 million, should suffice to significantly bridge the gap in broadband coverage in rural areas. However, this intervention is delayed: OPPIK was received late and in advance the thematic condition has not yet been met.

Czech Republic has not yet compiled a cost-cutting directive that could contribute to overcome infrastructure deficiencies. In 2015, the Czech Telecommunication Office (hereinafter referred to as the CTO) collected data and created a map coverage of the Czech Republic by high-speed internet. The map does not include mobile connections and was based on data reported by CTOs by the providers themselves. OPPIK announced the Broadband Internet Program. The aim of the program is to modernize and expand high-speed Internet infrastructure, especially focusing on so-called white spots where access is available networks do not yet exist. The program is designed for physical and legal persons operating publicly electronic communications networks. The amount of the subsidy is in the range of CZK 1 to 200 million. [3]

\subsection{Human Capital}

Results in human capital are just above the EU average but progress is slow. Czechs are relatively literate in the digital domain, and more than half of citizens have basic digital literacy skills. The number of graduates in technical, mathematical and scientific disciplines is stable, with 17 Czechs out of 1,000 in the age of 20-29, the same number as in the previous year and slightly below the EU average. But these people will be an important factor in selling digital and cutting-edge technologies. After which the government reacted with the approval of the Czech Republic's Digital Literacy Strategy for the period 2015-2020. Its aim is to prepare citizens for digital technology for the purpose of lifelong development and to improve the quality of their life integration into society. [8]

It has earmarked $€ 270$ million from the state budget and EU funds for the period 2015-2020. The strategy will mainly concern employees of SMEs and self-employed persons. The strategy aims to ensure that the workforce is digitally literate and to help employees (in particular SMEs and the self-employed) make full use of the potential of digital technologies, eliminate digital skills shortcomings and increase competitiveness. The various measures contained in the Digital Literacy Strategy represent an important step forward in the Czech Republic's digital literacy policy.

\subsection{Internet usage}

In the use of Internet services, the results of the EU are under-average and the progress is limited [14]. Czech Republic is involved in a wide range of online activities. Internet banking, shopping online, online news, music, movies, games, social networks are quite popular.

\subsection{Integrating digital technologies}

The EU is above average in this area, but progress is limited. SMEs are top-of-the-line on-line sales, but they are at risk of losing their position (dropping to the 6th place last year) [13]. Despite a certain slowdown, Czech companies use the possibilities and benefits offered by digital technologies to improve efficiency and productivity and gain access to a larger market.23\% SMEs offer on-line sales (compared to $16 \%$ in the EU as a whole) and $12 \%$ offer on-line sales of ido (compared with $8 \%$ in the EU as a whole).

\subsection{Digital public services}

Digital public services are below the EU average, but progress is being made. The low use of on-line public services is a result of the low supply of these services. Within the EU, the Czech Republic has the lowest shares of users of electronic public administration services. In 2015, only $12 \%$ of the Internet users sent forms to the public administration online, while the EU average was 32\%. In 2015, the Czech government approved the Strategy for the Development of ICT Services of Public Administration. 
The document summarizes the current state of affairs regarding the development of eGovernment, including the current lack of approvals. Specific measures are set out, including the definition of a larger role of the Government Council for the Information Society and the mandate of the Chief Architect of eGovernment at the Ministry of Internal Control over the efficiency of public spending in ICT governance. Within the framework of the Integrated Regional Operational Program co-financed by EU funds, a large amount of funds are required for the adoption of a new law regulating the obligation of all authorities to publish information in an open, machine-readable format and public administration responsibility to use secure domain names. [4]

\section{Conclusion and further development}

As has been said, the largest source of information and inspiration for the Czech approach to the Fourth Industrial Revolution is the German Industry Industries 4.0 initiative. It is necessary that the Czech Republic has responded to the industrial revolution as well, because this revolution brings a huge one opportunities in terms of sustainability and increased productivity of industrial production and services up to one-third. If that were not the case, the Czech Republic would not be able to keep its own competitiveness with other countries, and this would have an impact on productivity and employment, as well as the further development of the whole society. The Czech Republic is one from the most industrialized countries of Europe, especially thanks to the automotive industry, and therefore has a great deal a good starting position for further development.

The next procedure for the introduction of Industry 4.0 should correspond to the above mentioned Initiative Industry 4.0 and its proposals for action across areas of the entire infrastructure state management. These suggestions lead to the conclusion that the focus should be on the areas in which they are at a weaker level than is appropriate to create an enabling and supporting environment introducing the idea of Industry 4.0. This is primarily about supporting science, research and innovation, that is, focusing more on funding innovation centres, the emergence of new centres with a focus on innovative technology, better interdependence with universities, support for emerging companies - start-ups, etc. Another benefit would be to inspire, for example, the German Fraunhofer Institute, which, is concerned with projects focusing on innovation and new technologies. An integral part of the aid Industry 4.0 is to spread its ideas to the broader society and also to include it in educational institute programs. It is precisely because of changes in education that should be another Approaching the transition to Industry 4.0. These changes mean a change in methods teaching, content and extent of teaching.

Consideration should be given to future developments and associated with them the fact that quite a few jobs will be lost and, on the contrary, a new one will emerge, and just that change education should also be addressed. At the same time, students are educated too narrowly focused on the given area, they should be educated in the future in a more general way and then narrow their focus later into practice. A key role is played by support for digital economy and information and communication the technology through which the industry operates and is directly subject to these technologies. Of course, the previous steps must be the simultaneous creation of information documents and strategic materials that will be used to act and through which the Industry 4.0 concept will be further expanded. These are some of the most important starting steps that have to be taken so that the principles of the new industrial revolution can work in practice. Of course in Document Industry Initiative 4.0 contains many other terms and conditions, technological, legislative, ethical and other, which are very important for further development industry and the future of society.

\section{References}

This research was supported by the project SGS-2018-031 Optimizing the parameters of a sustainable production system.

\section{References}

[1] Sirůček, Pavel. Hospodářské dějiny a ekonomické teorie: (vývoj, současnost, výhledy).[ History and Economic Theories: (Development, Present, Perspectives).] Slaný: Melandrium, 2007. ISBN 978-80-86175-53-9.

[2] M. Šoltés, Roklen24.cz,. [Online]. Available: https://roklen24.cz/a/wEwiY/prumysl-40-jaka-je-startovni-poziceceske-republiky.

[3] Vysokorychlostní internet [Online]. Informační portál o dotacích pro podnikatele. [Information Portal on Grants for Entrepreneurs] Available:: http://www.oppik.cz/dotacni-programy/vysokorychlostni-internet

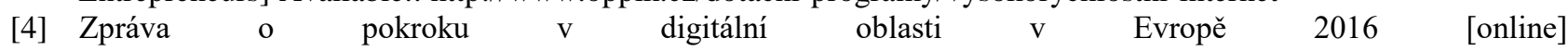
http://ec.europa.eu/newsroom/document.cfm?doc_id=44297 . Digital single market.

[5] Schumacher, A., S. Erol, and W. Sihn. 2016. "A Maturity Model for Assessing Industry 4.0 Readiness and Maturity of Manufacturing Enterprises.” Procedia CIRP 52: 161-166.10.1016/j.procir.2016.07.040

[6] Nikolic, Bojana, et al. "Predictive Manufacturing Systems in Industry 4.0: Trends, Benefits and Challenges." Annals of DAAAM \& Proceedings, vol. 28, Jan. 2017, pp. 796-802. EBSCOhost, doi:10.2507/28th.daaam.proceedings. 112 .

[7] J.A. Saucedo-Martínez, M. Pérez-Lara, J.A. Marmolejo-Saucedo Tomás Eloy Salais-Fierro, Pandian Vasant (2017) Industry 4.0 framework for management and operations: A review, Journal of Ambient Intelligence and Humanized Computing (2017), pp. 1-13 
[8] Broum, T., Gorner, T., Kleinova, J., Simon, M.: Increasing the value of ergonomic design of workplace in compliance with limit costs (2012) Proceedings of the International Conference of DAAAM Baltic "Industrial Engineering", $\quad$ pp. 413-418. https://www.scopus.com/inward/record.uri?eid=2-s2.084920510556\&partnerID=40\&md5=e744d3f00b161f0ca24ac482810c0ff4

[9] Kmec, Ján, Štefan Valenčík, Miroslav Gombár, Monika Karková a Alena Vagaská. Logistic Approach of Building and Development of Production System. Nase More, Dubrovnik: University of Dubrovnik, 2016, roč. 63, č. 3, s. 145-149. ISSN 0469-6255.

[10] Towards Programmer Knowledge Profile Generation / Emília Pietriková, Sergej Chodarev - 2016. In: Acta Electrotechnica et Informatica. Roč. 16, č. 1 (2016), s. 15-19. - ISSN 1335-8243

[11] Modification of production process structure and optimization of material flow for selected types of components computer simulation means / Petr Baron ... [et al.] - 2017. In: MM Science Journal. ol. 2017, no. November (2017), p. 1895-1900. - ISSN 1803-1269

[12] T. Stock, G. Seliger, Opportunities of Sustainable Manufacturing in Industry 4.0, Procedia CIRP, Volume 40, 2016, Pages 536-541, ISSN 2212-8271, https://doi.org/10.1016/j.procir.2016.01.129

[13] F. Shrouf, J. Ordieres and G. Miragliotta, "Smart factories in Industry 4.0: A review of the concept and of energy management approached in production based on the Internet of Things paradigm," 2014 IEEE International Conference on Industrial Engineering and Engineering Management, Bandar Sunway, 2014, pp. 697-701. doi: 10.1109/IEEM.2014.7058728

[14] Yang Lu, Industry 4.0: A survey on technologies, applications and open research issues, Journal of Industrial Information Integration, Volume 6, 2017, Pages 1-10, ISSN 2452-414X, https://doi.org/10.1016/j.jii.2017.04.005..

[15] F. Zezulka, P. Marcon, I. Vesely, O. Sajdl, Industry 4.0 - An Introduction in the phenomenon, IFAC-PapersOnLine, Volume 49, Issue 25, 2016, Pages 8-12, ISSN 2405-8963, https://doi.org/10.1016/j.ifacol.2016.12.002.

[16] Anna Szakállas, Tamás Orosz, István Vajda: Investigation of Applicability of Direct and Indirect Measurement Methods in the Engineering Education, 2014/1, Topical Problems in the Field of Electrical and Power Engineering: Doctoral School of Energy and Geotechnology, ISBN:978-9985-69-055-0 